\title{
The identity of Apostolepis pymi and placement of A. quinquelineata in the synonymy of $A$. nigrolineata (Serpentes, Xenodontinae)
}

\author{
Thales de Lema ${ }^{1,3}$ \& Nelson Rufino de Albuquerque ${ }^{2}$ \\ ${ }^{1}$ Av. Luiz Manoel Gonzaga, 100/1001, Petrópolis, CEP 90470-280, Porto Alegre, RS, Brazil \\ ${ }^{2}$ Universidade Federal de Mato Grosso do Sul - UFMS, \\ Campus do Pantanal, Departamento de Ciências do Ambiente, \\ Av. Rio Branco 1270, Universitário, CEP 79304-020, Corumbá, MS, Brazil \\ ${ }^{3}$ Corresponding author: Thales de Lema, e-mail: thalesdelema@terra.com.br
}

LEMA, T. \& ALBUQUERQUE, N.R. The identity of Apostolepis pymi and placement of A. quinquelineata in the synonymy of $\boldsymbol{A}$. nigrolineata (Serpentes, Xenodontinae). Biota Neotrop. 10(1): http://www.biotaneotropica. org.br/v10n1/en/abstract?short-communication+bn02810012010.

Abstract: The correct application of the names Apostolepis nigrolineata, A. quinquelineata, and A. pymi has been subject of considerable controversy. Based upon review of the literature and the characteristics used to distinguish these species from each other, we conclude that $A$. pymi is a valid species and that $A$. quinquelineata is a junior synonym of $A$. nigrolineata. They differ from each other in hemipenial morphology and coloration. The background color of A. nigrolineata is reddish brown (vs. brown in A. pymi). In addition, only the dorsal region of end of tail is covered by a black band in A. nigrolineata (vs. end of tail completely surrounded by a black band in A. pymi). Both species are sympatrically distributed along the lowlands of Amazonia but A. nigrolineata occurs in both western and eastern regions whereas A. pymi is restricted to eastern regions with additional records from the States of Amazonas, Rondônia, Mato Grosso and an endemic population in the state of Ceará, northeastern Brazil.

Keywords: Dipsadidae, Apostolepis, taxonomy, synonymization, amazon region.

LEMA, T. \& ALBUQUERQUE, N.R. A identidade de Apostolepis pymi e colocação de A. quinquelineata na sinonímia de A. nigrolineata (Serpentes, Xenodontinae). Biota Neotrop. 10(1): http://www.biotaneotropica. org.br/v10n1/pt/abstract?short-communication+bn02810012010.

Resumo: A correta aplicação dos nomes Apostolepis nigrolineata, A. quinquelineata, e A. pymi tem sido assunto de considerável controvérsia. Baseado em uma revisão da literatura e das características usadas para distinguir essas espécies umas das outras, nós concluímos que A. pymi é uma espécie válida e que A. quinquelineata é um sinônimo júnior de Apostolepis nigrolineata. Elas diferem uma da outra na morfologia hemipeniana e coloração. A coloração dorsal de A. nigrolineata é marrom avermelhada (vs. marrom em A. pymi). Em adição, apenas a região dorsal do final da cauda de A. nigrolineata é coberta por uma banda preta (vs. o final da cauda é completamente envolto por uma banda preta em A. pymi). Ambas as espécies ocorrem dentro da Amazônia, mas A. nigrolineata ocorre nas regiões oeste e leste enquanto A. pymi é restrita para regiões do leste com registros adicionais para os estados do Amazonas, Mato Grosso, Rondônia e mais uma população endêmica no estado do Ceará, nordeste do Brasil.

Palavras-chave: Dipsadidae, Apostolepis, taxonomia, sinonimização, região amazônica. 


\section{Introduction}

The snake genus Apostolepis Cope, 1862 is a diverse new world group of fossorial snakes distributed throughout South America, occurring from Guyana to northern Argentina, and from northeastern to southeastern Brazil (Lema \& Renner 1998, Lema 2001). These snakes have had a long and confusing taxonomic history (e.g. Amaral 1930a, b, Hoge 1959, Cunha \& Nascimento 1978), in part due to their coloration and morphological similarity (see Harvey 1999, Lema 2001), which resulted in numerous misidentifications and synonymies within this genus. This has been particularly true with the recently revalidated A. nigrolineata (Peters, 1869) and one of its synomies, A. pymi Boulenger 1903. The nomenclatural history of these two species is summarized herein:

Peters (1869) described Elapomorphus nigrolineatus based on one specimen from Guyana (Lema 2001). Strauch (1885), who made the first revision of the Elapomorphinae snakes, redescribed the holotype of E. nigrolineatus. Boulenger (1896) described Apostolepis quinquelineata based on one specimen from Demerara, Guyana. Subsequently, Boulenger (1903) described Apostolepis pymi based on one specimen from "Brazil", later restricted to Pará State by Lema (1997).

Amaral (1930a, b) considered Apostolepis pymi and $A$. quinquelineata to be synonymous with $A$. coronata, described by Sauvage (1877) as Elapomorphus coronatus, based on one specimen from "Amérique du Sud" (Rio de Janeiro) (Lema \& Hofstadler-Deiques 1995). Amaral (1930a) noted that the five black stripes are reduced and disappear in adult specimens of Apostolepis pymi; he also considered the holotype of A. pymi as a juvenile specimen. Subsequently, Amaral (1930b) considered A. nigrolineata to be synonymous with A. flavotorquata (Duméril et al.1854), the latter described based on one specimen from "l'intérieur de l'Amérique méridionale" (Goiás State) (according to Strauch 1885).

Apostolepis pymi and A. quinquelineata were considered to be synonymous by Cunha \& Nascimento $(1978,1993)$, who redescribed A. quinquelineata based on the examination of several specimens from eastern Pará.

Apostolepis nigrolineata was recently revalidated by Lema (1997) to accommodate specimens previously listed as A. pymi. Lema (1997) re-examined the holotype of $A$. nigrolineata and considered $A$. pymi as a junior synonym of Apostolepis nigrolineata. Finally, Lema (2001) kept $A$. pymi in the synonymy of $A$. nigrolineata.

Based upon review of the literature, we discussed the taxonomic status of A. nigrolineata and A. pymi. Both species have long been misidentified in the literature and the distinctness between them is given.

\section{Material and Methods}

We reviewed all articles that dealt with the names A. nigrolineata, A. quinquelineata, and A. pymi (see species accounts in Appendix 1). Subsequently, we focused our review only in those articles that dealt specifically with nomenclatural changes (e.g. Amaral 1930a, b, Lema 1997, Lema \& Renner 1998) and the characteristics used by various authors to distinguish species from each other. Apostolepis rondoni Amaral, 1925, known only from the holotype, was considered to be a junior synonym of A. quinquelineata by Lema \& Renner (1998) and is therefore not included in our review (see also Cunha \& Nascimento 1978, Silva Jr. 1993). The specimen depicted in Figures 1 and 2 is deposited in the Coleção de Anfíbios e Répteis do Museu de Ciências e Tecnologia da PUCRS (MCP) as MCP 10718.

\section{Results and Discussion}

Except for its original description (Boulenger, 1903) the species Apostolepis pymi has been consistently misidentified

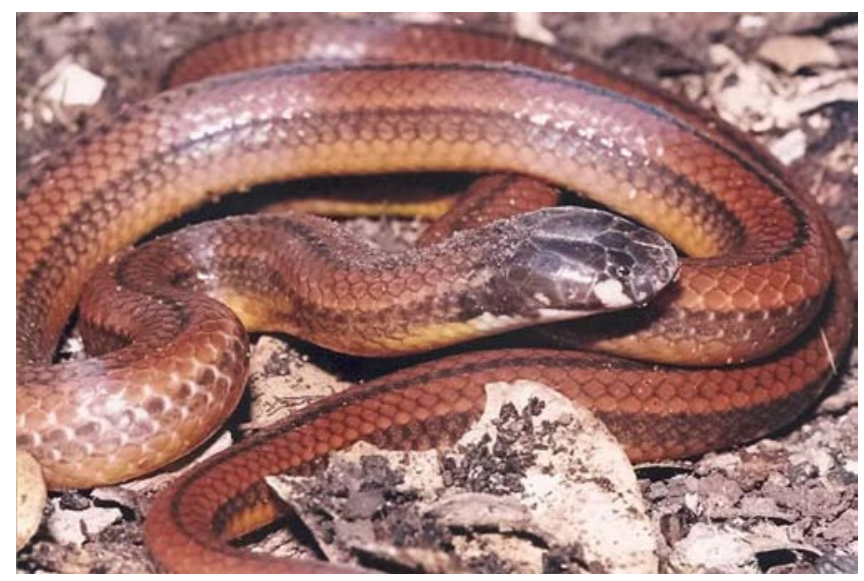

Figure 1. Dorsal view of Apostolepis nigrolineata (MCP 10718, an adult male) from ilha de Outeiro, vicinity of Belém, Pará, Brazil (Photo credit: Marcos Di-Bernardo). Note three distinct dorsal stripes.

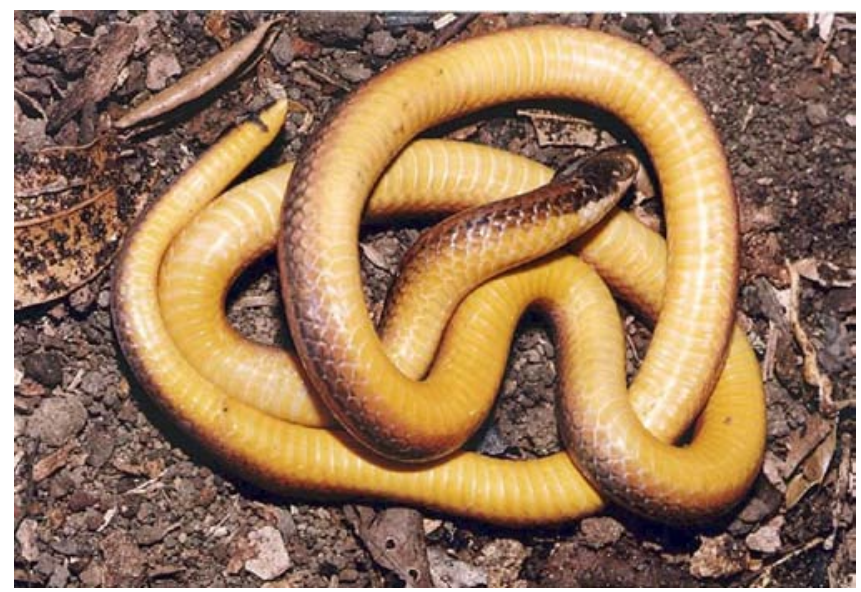

Figure 2. Ventral view of Apostolepis nigrolineata (MCP 10718, an adult male) from ilha de Outeiro, vicinity of Belém, Pará, Brazil (Photo credit: Marcos Di-Bernardo). Note the ventral region of the tail is almost entirely immaculate. A small black spot can be observed on the $30^{\text {th }}$ pair of subcaudal scales.

throughout the literature (e.g. Amaral 1930a, b, Hoge 1959, Cunha \& Nascimento 1978, Nascimento \& Lima-Verde 1989, Lema 1978). Similarly, A. nigrolineata has received several different names such as Elapomorphus (Apostolepis) nigrolineatus Strauch, 1885, A. nigrolineata, A. quinquelineata Boulenger, 1896, and A. rondoni.

While reviewing the status of A. nigrolineata, Lema (1997) re-examined three specimens of $A$. nigrolineata, including its holotype, and recognized this species as a synonym of $A$. pymi. The number of dorsal stripes in both species is five, although it reduces to three in adults. Adults of both species retain evidence of paravertebral stripes; however, these are almost indiscernible (Lema \& Renner 1998). This similarity (i.e. five stripes in young specimens) led Lema (1997) to recognize the holotype of A. nigrolineata as a juvenile of A. pymi. It should be emphasized that most specimens of A. nigrolineata examined by Lema \& Renner (1998) (identified as $A$. quinquelineata in their paper) are juveniles. We reidentified the specimen identified as A. nigrolineata for Guaporé river, Mato Grosso by Lema (1997: 197) as A. pymi. Actually, this specimen (UFMT 2500) was collected in a patch of seasonal semideciduous forest located in Vale de São Domingos, Mato Grosso. 
Apostolepis nigrolineata can be easily distinguished from Apostolepis pymi by the following combination of characters: dorsum reddish brown (Figure 1) (vs. dorsum brown); a blackish brown head (vs. a dark brown head) lacking a pair of cream blotches on preocular scales (vs. a pair of cream blotches occupying almost whole of prefrontal scales); a pair of cream blotches on neck covering the 3rd and 4th dorsal scales on 5th scale row on each side (see Figure 1 in Lema \& Renner 1998) (vs. blotches absent). The caudal band is dark brown in A. nigrolineata and covers only the dorsal surface of the end of the tail (caudal band covers ventral and dorsal surfaces in A. pymi). Further, the tip of the tail is conical (pointed) in A. nigrolineata (vs. rounded in A. pymi).

According to Lema \& Renner (1998), A. nigrolineata (identified as $A$. quinquelineata) and $A$. pymi occur sympatrically from the eastern region of Amazonas to western Pará. The specimen collected in the ilha de Outeiro, Pará State (Figure 1) extends eastward to the previously known zone of sympatry. Data from external morphology and hemipenial morphology can be found in Lema \& Renner (1998).

In summary, Lema (1997) erroneously considered A. pymi as a synonym of $A$. nigrolineata. Instead, $A$. pymi is the correct name for the species of this complex occurring mainly in eastern Amazonia (Lema \& Renner 1998). Apostolepis nigrolineata is a senior synonym of both A. quinquelineata and A. rondoni and is the species occurring in western Amazonia. Both species were described and reviewed by Lema (1997) and Lema \& Renner (1998) who used the name A. quinquelineata instead of A. nigrolineata.

\section{Acknowledgements}

Colin McCarthy read an early version of the manuscript and provided valuable suggestions. Francisco L. Franco and one anonymous reviewer greatly improved this final version. Robert Pascocello kindly reviewed and corrected the orthography.

\section{References}

AMARAL, A. 1925. Ophidios de Matto Grosso (Contribuição II para o conhecimento dos ophidios do Brasil). Comm. Linhas Telegraph. Estrat. Matto Grosso ao Amazonas. Hist. Natural. Zool. 84(5):1-29.

AMARAL, A. 1930a. Estudos sobre ophidios neotropicos. XVII. Valor systematico de varias formas de ophidios neotropicos. Mem. Inst. Butantan 4(1929):32-68.

AMARAL, A. 1930b. Estudos sobre ophidios neotropicos. XVIII. Lista remissiva dos ophidios da região neotropica. Mem. Inst. Butantan 4(1929):129-271.

AMARAL, A. 1936. Contribuição ao conhecimento dos ophidios do Brasil. VIII. Lista remissiva dos ophidios do Brasil. 2 ed. Mem. Inst. Butantan 10:87-162.

AMARAL, A. 1944. Notas sobre a ofiologia Neotrópica e Brasílica. IX. Formas de boigíneos de recente registro. Pap. avulsos Dep. Zool. 5:65-74.

AMARAL, A. 1977. Serpentes do Brasil: Iconografia Colorida. Editora Melhoramentos, São Paulo.
BOULENGER, G.A. 1896. Catalogue of the snakes in the British Museum. Taylor and Francis Press, London.

BOULENGER, G.A. 1903. Descriptions of new snakes in the collection of the British Museum. Ann. Mag. Nat. Hist. 7(12):350-354.

CUNHA, O.R. \& NASCIMENTO, F.P. 1978. Ofídios da Amazônia X - As cobras da região Leste do Pará. Publ. Avul. Mus. Para. Emílio Goeldi 31:1-218.

CUNHA, O.R. \& NASCIMENTO, F.P. 1993. Ofídios da Amazônia X As cobras da região Leste do Pará. Bol. Mus. Para. Emilio Goeldi 9(1):1-191.

HARVEY, M.B. 1999. Revision of Bolivian Apostolepis (Squamata: Colubridae). Copeia (2):388-409.

HOGE, A.R. 1959. Étude sur Apostolepis coronata (Sauvage 1877) et Apostolepis quinquelineata Boulenger 1896. Mem. Inst. Butantan. 28:73-76.

LEMA, T. \& HOFSTADLER-DEIQUES, C. 1995. Estudo revisivo de Elapomorphus lepidus Reinhardt com a invalidação de E. wuchereri Günther, E. accedens Jan e E. coronatus Sauvage mediante análise tipológica e a osteologia craniana (Serpentes, Colubridae, Xenodontinae, Elapomorphini). Biociências 3(1):91-143.

LEMA, T. \& RENNER, M.F. 1998. O status de Apostolepis quinquelineata Boulenger, 1896, A. pymi Boulenger, 1903 e A. rondoni Amaral, 1925 (Serpentes, Colubriae, Elapomorphini). Biociências 6(1):99-121.

LEMA, T. 1978. Novas espécies de opistoglifontes do gênero Apostolepis Cope, 1861 do Paraguai (Ophidia: Colubridae: Colubrinae). Comun. Mus. Ci. PUCRGS. 18/19:27-49.

LEMA, T. 1997. A redescription of the tropical Brazilian serpent Apostolepis nigrolineata (Peters, 1869), (Colubridae: Elapomorphinae), synonymous with A. pymi Boulenger 1903. Stud. Neotrop. Fauna E. 32(1):193-199.

LEMA, T. 2001. Fossorial snake genus Apostolepis from South América (Serpentes: Colubridae: Elapomorphinae). Cuad. Herpetol. 15(11):29-43.

NASCIMENTO, F.P. \& LIMA-VERDE, J.S. 1989. Ocorrência de ofídios de ambientes florestais em enclaves de matas úmidas do Ceará (Ophidia: Colubridae). Bol. Mus. Para. Emilio Goeldi, sér. Zool. 5(1):95-100.

PETERS, J.A. \& OREJAS-MIRANDA, B. 1970. Catalogue of the Neotropical Squamata: Part I. Snakes. U.S. Nat. Mus. Bull. 297:347.

PETERS, W. 1869. Üeber neue Gattungen und neue oder weniger bekannte Arten von Amphibien (Eremias, Dicrodon, Euprepes, Lygosoma, Typhlops, Eryx, Rhynchonyx, Elapomorphus, Achalinus, Coronella, Dromicus, Xenopholis, Anoplodipsas, Spilotes, Tropidonotus). Monatsber. Deutsch. Akad. Wiss. 1869:432-447.

SAUVAGE, H.E. 1877. Sur quelques ophidiens d'espèces nouvelles ou peu connues de la collection du Muséum. Bull. Soc. Philom. 7(1):107-115.

SILVA Jr., N.J. 1993. The snakes from Samuel Hydroelectric Power Plant and vicinity, Rondônia, Brazil. Herpetol. Nat. Hist. 1(1):37-86.

STRAUCH, A. 1885. Bemerkungen über die Schlangengattung Elapomorphus aus der Familie der Calamariden. Bull. Acad. Imp. Sci. 29:541-590.

Received 30/10/09

Revised 09/03/10

Accepted 22/03/10 


\section{Appendix 1}

Appendix 1. Species Accounts.

Apostolepis nigrolineata (Peters 1869)

Elapomorphus nigrolineatus Peters (1869), type-locality: given as "Guinea”, but assumed by Lema (2001) to be Guyana.

Elapomorphus (Apostolepis) nigrolineatus; Strauch, 1885

Apostolepis nigrolineata; Boulenger, 1896; Lema, 2001

Apostolepis quinquelineata Boulenger (1896), type-locality Demerara, Guyana. Hoge, 1958; Peters and Orejas-Miranda, 1970; Cunha and Nascimento, 1978; Cunha and Nascimento (1993); Lema, 1978; Lema and Renner, 1998

Apostolepis rondoni Amaral (1925), type-locality Rondon, Rondônia, Brazil. Amaral, 1977; Silva, 1993

Apostolepis coronata; Amaral (1930a, b, 1936, 1944).

Distribution. Apostolepis nigrolineata occurs within the Amazon basin, from Guyana to western Amazonas, Rondônia and Pará States (Lema \& Renner 1998, identified as Apostolepis quinquelineata).

Apostolepis pymi Boulenger (1903)

Apostolepis pymi Boulenger (1903), type-locality: "Brazil”; restricted by Lema (1997) to Pará State

Apostolepis quinquelineata; Amaral, 1930a; Hoge, 1958; Cunha and Nascimento (1978, 1993); Nascimento and Lima-Verde, 1989.

Apostolepis coronata; Amaral (1930a, b, 1936); Peters and Orejas-Miranda, 1970.

Apostolepis flavotorquata; Amaral, 1930a; Lema, 1978.

Apostolepis nigrolineata; Lema, 2001.

Distribution. Apostolepis pymi is known from eastern Pará to western Maranhão, with additional records from the states of Amazonas, Mato Grosso, Rondônia and Ceará (Lema \& Renner 1998). 